\section{THE DURHAM COALFIELD}

$\mathrm{T}$ HE fuel technologist, the mining engineer and the geologist will find material of interest in the Regional Survey Report on the Durham Coalfield*. The pressing needs of war have revealed serious defects in the organization and technical efficiency of British coal-mining, and the Minister of Fuel and Power has wisely decreed that the basis of any attempt to create an efficient and prosperous mining industry is a national stock-taking of the already depleted coal resources of Great Britain.

At an early stage in the report it is made clear that this coalfield has made, and will continue to make, a vital contribution to the national economy. Durham coals vary much in character; but this area is justly renowned for its coking and gas coals, described as "probably the best in Europe". In West Durham eertain of the seams yield coal which produces an excellent metallurgical coke, hard in texture and low in sulphur and phosphorus-a coke in great demand for foundry and general metallurgical work. Emphasis is very properly laid on the fact that the seams yielding the best coking coals have but a limited life, and it is estimated that, at present rates of production and consumption, the total coking coal reserves will be extracted within seventy years. The conservation of these resources of coking coal is clearly a matter of first importance, and the report makes a significant reference to the considerable export trade prevailing in this class of coal in normal times. Almost the whole of the coalfield produces gas coals of good quality. Much of the coal required. by the gas works of London and the south coast comes from Durham, and prior to the War, Durham coal was shipped to many of the European gas works.

There has been much speculation as to the probable life of the British coal seams ; but it is certain that the regional surveys will provide data for reasonably accurate estimates. Since previous attempts to arrive at the coal reserves of Great Britain much information has been compiled by the Geological and Fuel Research Surveys, while the financial transaction involved in the nationalization 'of mineral royalties necessitated the preparation of proposals for working during the next thirty years, with an estimate of the reserves remaining in 1972. With certain reservations, the estimated reserves of the Durham Coalfield are given as 3,000 million tons. It appears that this is a conservative estimate; many thin and low-quality seams are not included in the figure, and it is also probable that there are further substantial reserves of under-sea coal. In 1938, the output was approximately thirty-three million tons, so that at this rate of production much of the Durham Coalfield will be exhausted in the next hundred years. Nevertheless, coal will continue to be produced from this area for a much longer period; seams not now regarded as a commercial proposition may well prove workable in the years ahead, "providing, as it were, a second harvest".

The conditions prevailing in the under-sea areas are of great importance to the coalfield. It is disappointing to read that there are deteriorations in certain seams as they pass seawards. The Durham Coalfield is apparently affected in the same way as the East Midland Coalfield, which suffers a marked deterioration in the seams underlying its eastward

* Ministry of Fuel and Power : Durham Coalfleld Regional Survey Report (Northern "B" Region). Pp. 48. (Iondon: H.M. Stationery Office, 1945.) 18, net. extension. Exploration has been carried to a small distance beyond the three-mile limit, but it is expected that one or two of the better seams will be workable for a distance of six miles or more out to sea.

An astonishing feature of the report is the statement that some 738 million tons of coal have been sterilized for one reason or another. The bulk of this coal has been left in order to avoid damage to buildings by mining subsidence, and the report states that if arrangements could be made for supporting the surface by stowage, some 468 million tons of this sterilized coal might well prove economically workable. Since sterilized coal has not been included in the estimate of total reserves, and represents about 25 per cent of the latter figure, it is clear that the introduction of modern methods of stowage would result in a considerable addition to the resources of the coalfield. To obviate further undue sterilization of Durham coal, care is needed in the selection of sites for future houses and buildings.

The industrial life of this area is based on its highquality coal seams, and any consideration of future prospects must take into account the possibilities of using coal as a basic raw material. Included in the report is a short account of the findings of the Coal Processing Industries Panel of the North-East Chemical and Allied Industries Development Committee. It is made clear that the establishment of new coal-processing industries will involve a very large capital expenditure, and that the success of any project of this nature will be dependent on adequate coordination. "The Gas-Grid Scheme, the extraction of olefines, methane and other gases, the production from these of chemicals and plastics, the conversion of coke to petrol, Diesel oil and other hydrocarbons, are all inter-related, and part of one comprehensive coal processing project."

The remainder of the report deals with the possibilities of de-watering a large tract of flooded coal in south-west Durham, the question of increasing productivity by further mechanization of the mines, and the housing requirements of the mining community. As a guide to the present position and future of the coalfield, the report is a document of major importance, of interest to all who believe that the future of Britain is dependent on the proper use of our remaining coal resources.

H. Hartley.

\section{REFORM OF THE PATENT LAW IN BRITAIN}

$\mathrm{D}$ URING the past few years, there have been many allegations that monopoly rights created by patents for inventions are being used contrary to the public interest by large industrial corporations. One suggestion which has been mooted in Great Britain for rectifying this alleged abuse is that each patent shall be granted subject to the condition that any person may obtain a licence to work the invention on terms to be agreed with the patentee or, in case of disagreement, to be settled by the Comptroller-General of Patents. This suggestion, in its original form, has not met with general acceptance, and a modification of it is put forward by Prof. M. Polanyi in a pamphlet reprinted from the Review of Economic Studies, entitled "Patent Reform: a Plan for Encouraging the Application of Inventions".

Prof. Polanyi expresses the opinion that to grant all patents subject to compulsory licensing on terms 
to be settled by the Comptroller would produce practically the same results as if patents had been abolished altogether; he suggests an alternative system under which licensing is supplemented by Government rewards to patentees on a level ample enough to give general satisfaction to inventors and their financial promoters. In operating the system, patents would be granted by the Patent Office in accordance with the present law and, shortly after the patent had been granted, the Comptroller would lay down obligations to be fulfilled by licensees. These obligations would have only one purpose, namely, to ensure the assessment of the economic values created by the invention. Licensees would have to make returns to patentees on certain technical points designated to them and, on these returns, patentees would base their own assessment of the economic value created by the invention. The Government would undertake to pay annually to patentees a fixed fractional part--perhaps one-tenth to one-third - of the approved total of assessed values created by the invention during the previous year. It is an integral part of the system that public rewards should be so adjusted as to make them sufficiently attractive to inventors and backers of inventions in general. In many cases, the process of assessing the economic value of the invention for purposes of rewarding the patentees might be carried out directly by Government inquiry, to the exclusion of any reports by licensees to patentees.

It is claimed by Prof. Polanyi that under the existing system the presence of the attributes of novelty, utility and subject-matter in each invention leads to serious abuses of legalism and to consequent inequitable remuneration of inventors, and that his system would provide an equitable reward for each of the investigators taking part in the production of a patentable invention. He foresees, however, two dangers, though he is of opinion that each can be avoided. In order to obviate the danger of corruption and arbitrary oppression, which is never far removed. from the grant of Government subsidies, the whole procedure of their assessment should be made fairly rigid, by requiring the returns on which they are based to include only data endorsable by accountants' certificate. Further, in his opinion, the fact that considerable sums of public money would be required under his system, in order to pay rewards to patentees, cannot be held against it because the burden would be more than offset by the benefits accruing to the public.

It is possible that in respect of each of these dangers Prof. Polanyi is too optimistic. The reluctance of the British Government to provide public money to produce benefits that cannot be readily shown to be due to the money so used is well known; and it is not at all certain that a Govornment would provide an amount of public money that would be accepted as adequate by patentees and their financial backers, and at the same time be recognized. by the public as justifiable.

Further, experience has shown that the danger of corruption and arbitrary oppression is not easily avoided. One outstanding example of direct government rewards to inventors is the system at present in operation in the U.S.S.R. There, a special form of patent protection was established in 1931 which entitled the inventor to receive certain fixed compensation and various living or social privileges, and which contained elaborate provisions for the testing and exploitation of inventions. On March 5, 1941, the Council of People's Commissars of the U.S.S.R. promulgated a decree introducing a new "Inventions Statute" and repealing the former one dated April 9, 1931. The following extract from Pravda of April 15, 1941, stated its objects :

"The main object of the revision is to establish a definite procedure for examining and consummating inventions and technical improvements and to give a number of privileges to inventors to protect them from bureaucrats and procrastinators.

"The Statute establishes definite periods within which offers of inventions and technical improvements must be accepted or rejected, or definite tests inaugurated. The reason for these rigid regulations is that we have not yet got rid of our bureaucrats, who beat off inventors like importunate flies. There are inventors who for five years have been sitting on the doorsteps of commissariats, trusts, newspaper offices and complaints offices in a vain endeavour to get an answer as to the fate of their proposals".

Even if Prof. Polanyi's hope of avoiding these dangers is realized, it is not clear how his system will overcome the fundamental difficulty raised by compulsory licensing of all patents. So far as Great Britain is concerned, after an inventor has obtained the grant of a patent, either he or his financial backers must provide the capital necessary to work the invention in this country on a commercial scale if it is desired to retain the monopoly. If the monopoly is lost by compulsory licensing, the difficulty of providing this capital will be increased; for not many inventors or their financial backers will be prepared to erect plant for the commercial exploitation of an invention with the risk that it may be a failure, if their competitors are at liberty to obtain a licence should it be a success.

\section{CAROTENE AND SUGAR CONTENT OF CARROTS}

$\mathrm{T}$ HE nutritional value of carrot roots is due largely to their contents of carotene and sugar, and both these constituents are most abundant in the phloem. It is of interest to note, therefore ${ }^{\mathrm{I}}$, that although the phloem constitutes more than 60 per cent of the root the proportion is greatest in young roots, although caroten $\Theta$ content increases with maturity but is least in 'large strain' carrots ${ }^{2}$. Carotene content is influenced by manuring, but carotene losses during storage are negligible until the stored roots sprout in the spring. Although sugar content is often a good index of 'quality', the correlation between desirable taste and refractive index of the juice is often upset by the presence of an unidentified bitter constituent ${ }^{3}$.

Maintenance of high quality (that is, high sugar stocks) may be difficult, as these roots when replanted for seed production often rot and so fail to produce a satisfactory crop of seed ${ }^{4}$. Seed production, too, may be complicated by the temperature requirements of the carrot ${ }^{5}$, H. S. Sakr and H. C. Thompson reporting that the initiation of flower primordia is inhibited at temperatures in excess of $70^{\circ} \mathrm{F}$. although doubtless the critical inhibiting temperature is influenced by the previous history of the carrot.

Not less important than the taste and sugar content is the shape of the roots, and traditionally carrots are grown on land "manured for a previous crop", fresh animal manure being thought to induce 